\title{
Working
}

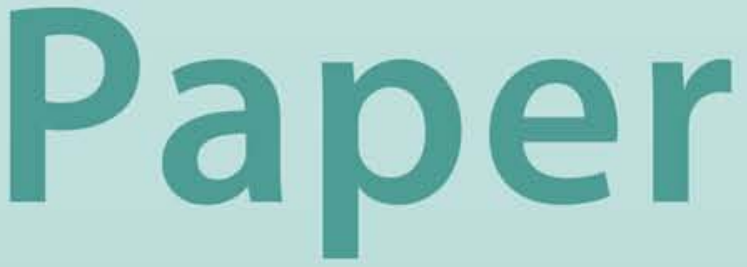


Hedging Government Oil Price Risk

James A. Daniel 


\title{
IMF Working Paper
}

\author{
Fiscal Affairs Department
}

\section{Hedging Government Oil Price Risk}

\author{
Prepared by James A. Daniel ${ }^{1}$ \\ Authorized for distribution by Jeffrey M. Davis
}

November 2001

\begin{abstract}
The views expressed in this Working Paper are those of the author(s) and do not necessarily represent those of the IMF or IMF policy. Working Papers describe research in progress by the author(s) and are published to elicit comments and to further debate.
\end{abstract}

Many governments are heavily exposed to oil price risk, especially those dependent on revenue derived from oil production. For these governments, dealing with large price movements is difficult and costly. Traditional approaches, such as stabilization funds, are inherently flawed. Oil risk markets could be a solution. These markets have matured greatly in the last decade, and their range and depth could allow even substantial producers, and consumers, to hedge their oil price risk. Yet governments have held back from using these markets, mainly for fear of the political cost and lack of know how. This suggests that the $\mathrm{IMF}$, together with other development agencies, should consider encouraging governments to explore the scope for hedging their oil price risk.

JEL Classification Numbers: E64; O23; Q48.

Keywords: Oil; hedging; fiscal policy; derivative markets.

Author's E-Mail Address:jdaniel@imf.org

\footnotetext{
${ }^{1}$ I would like to thank Steven Barnett, Juan Pablo Cordoba, Jeffrey Davis, Alan Gelb, Rolando Ossowski, Alvaro Vivanco, and Peter Wickham for comments on earlier versions of this paper. Alavaro Vivanco also provided excellent research assistance. All remaining errors are mine.
} 


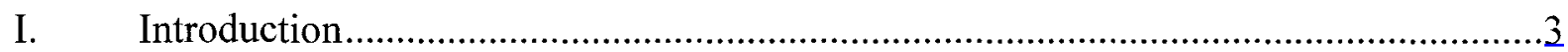

II. Why Oil Price Risk Matters to Governments ...................................................

III. Why Oil Price Risk Markets Could be a Solution .................................................5

Hedging simulations ........................................................................

Hypothetical hedging simulations for Mexico.................................... 10

The over-the-counter (OTC) market ..................................................

IV. Why Governments Are Not Using Oil Price Risk Markets ...................................12

The politics of hedging .......................................................................13

Market volume .................................................................................14

Creditworthiness and use of reserves......................................................15

Fairness of futures prices ............................................................. 15

Institutional capacity and operational risk ............................................16

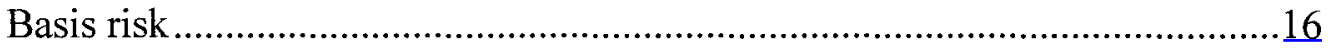

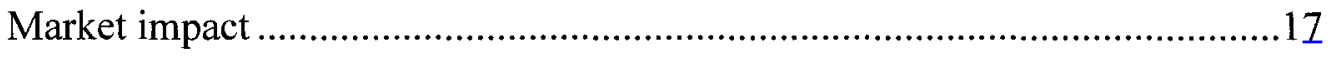

V. Relevance for IMF-supported programs ......................................................17

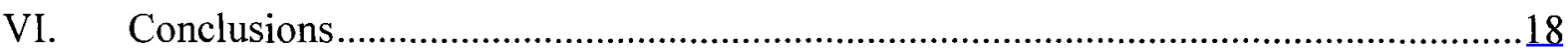

Text Table

1. Oil Revenue Dependence for Selected Major Exporters, 2000 .....................................5

Figures

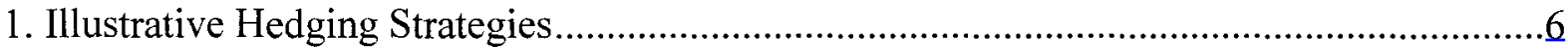

2. WTI Crude 12-month Futures vs. Spot Prices by Contract Month, 1990-2001 _..................

3. Average Crude Oil Futures Prices Grouped by Spot Price, 1983-2001 ............................8

4. Spot Price vs. Options Hedging Strategy, 1990-2001 ....................................................

5. Mexican Spot Export Oil Prices and Hypothetical Hedged Price Using 12-Month WTI

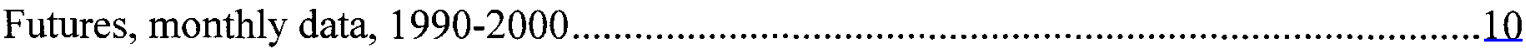

Boxes

1. The Main Over-the-counter Commodity Risk Instruments ........................................12

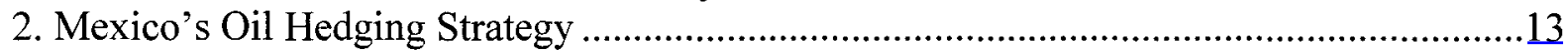

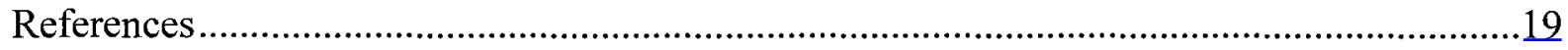




\section{INTRODUCTION}

Oil price risk is the risk that oil prices may change rapidly, substantially, and unpredictably. Governments bear this risk in two main ways. Governments of oil-producing countries often rely heavily on revenue from oil production. Governments that administratively set oilrelated product prices will suffer financially when the input price rises if they do not raise output prices. And, in both cases, governments will be very aware of the social, political, and economic cost of volatile oil prices. Governments have tried to deal with the problem of their oil price risk exposure in a variety of ways, for example, stabilization funds. But these methods are, to a greater or lesser extent, flawed, as the government is still bearing oil price risk which it is inherently ill-suited to bear.

Oil price risk markets seem a possible solution, at least theoretically. The principle is quite simple. Governments could either lock-in the price of their future production or consumption now, or insure against large oil price moves, or both. In this way, rather than trying to cope with a volatile and unpredicable revenue stream, the revenue stream itself is made more stable and predictable. This paper aims to explore whether this simple theoretical solution to managing government oil price risk might be able to work in practice and if it can, what is preventing governments from doing it.

\section{Why Oil Price Risk Matters to Governments}

Governments typically bear two kinds of oil price risk. First, and foremost, many governments obtain substantial revenue from oil production/exportation. Second, many governments also try to smooth domestic oil-product prices to mitigate the social, economic, and political impact of large and frequent changes in oil product prices. In both cases, the fiscal position of the government depends substantially on the oil price.

Such oil price risk is difficult for governments to bear. In the absence of financing opportunities, when prices go down (or up for oil consumers ${ }^{2}$ ) governments have to cut expenditure or raise other revenue. This is difficult to do quickly and especially difficult to do efficiently. It is also likely to make fiscal policy pro-cyclical, to put a heavy burden on the private sector and the poor, lead to macroeconomic instability (e.g., monetary financing, exchange rate fluctuations, debt rescheduling, and variable economic growth), and social and political unrest. Increasing spending when prices rise is easier but difficult to do efficiently. More generally, reliance on oil revenue leads to stop-go fiscal policy. Other problems include the difficulty of planning, for example, basing a budget on oil price assumptions that could turn out to be very wrong. And when price assumptions do turn out to be wrong, governments immediately feel the revenue impact as their revenue depends on the spot price of oil.

${ }^{2}$ The emphasis in the paper is on governments heavily dependent on oil revenue rather than governments that smooth domestic oil-product prices. However, most of the arguments apply equally to both. 
To help deal with oil price risk, many governments have established oil stabilization funds. In the case of oil producers, the idea is that a stabilization fund would smooth out the fluctuations in the international price of oil and stabilize the stream of government oil revenue. This would work by the fund accumulating resources when the international spot price is above its reference price and vice versa. For oil consumers, the fund would work in reverse: the fund would subsidize domestic consumption when the spot price is above its reference level and vice versa.

But stabilization funds are inherently flawed. ${ }^{3}$ Because the international oil spot price does not have a well-defined time-invariant "equilibrium" value to which it returns, funds based on rigid transfer rules are likely to be overwhelmed by oil price shocks, as such shocks are often large and long lasting. More generally, funds do not stabilize government finances unless accompanied by other policy actions, such as expenditure restraint, as resources are fungible. For example, government expenditure is not directly affected by stabilization funds as governments can typically borrow to finance expenditure while still meeting their obligations to the stabilization fund during times of "high" oil prices. Moreover, stabilization funds will likely create duplications, overlaps and inefficiency in the management of public resources, complicate fiscal policy making, and may foster poor governance and damage transparency.

Instead of setting up an explicit stabilization fund, governments can borrow (or run down assets) abroad when the international price goes against them. (Domestic financing would just pass on the shock to the domestic private sector.) Provided such financing is used to buy time to ride out temporary shocks or to adjust to permanent oil price shocks, this approach is attractive in theory. The problem is that just when a country needs the financing, it is likely to be least able to obtain it. For example, an oil exporter will find it hardest to raise financing when the oil price plummets. Also, many countries do not have access to significant amounts of foreign assets. Further, it is politically difficult to generate the corresponding surplus to repay the debt when the situation is reversed, leading to solvency problems.

The size of the oil price risk borne by governments can be very large and not necessarily linked to the global importance of a country's oil exports (Table 1). For example, oil revenue accounted for 51 percent of GDP in 2000 for Angola ( 90 percent of total revenue and grants). However, Angola accounts for less than 1 percent of global crude plus petroleum exports. In contrast, oil revenue in Norway, one of the world's most important oil exporters, accounted for only about 13 percent of GDP in 2000 (29 percent of total revenue). Moreover, the change in oil revenue from year to year for governments highly dependent on oil revenue can be massive. For example, Yemen's oil revenue increased from 18 percent of GDP in 1999 to 33 percent of GDP in 2000.

\footnotetext{
${ }^{3}$ See IMF Occasional Paper 205, "Stabilization and Savings Funds for Nonrenewable Resources: Experience and Fiscal Policy Implications."
} 
Table 1. Oil Revenue Dependence for Selected Major Exporters, 2000

\begin{tabular}{|c|c|c|c|c|}
\hline & \multicolumn{2}{|c|}{$\begin{array}{l}\text { Government Hydrocarbon Revenue } \\
\text { In Percent of Total }\end{array}$} & \multicolumn{2}{|c|}{ Crude + Petroleum Exports (1998) } \\
\hline & $\begin{array}{c}\text { In Percent of Total } \\
\text { Revenue } \\
\end{array}$ & In Percent of GDP & $\begin{array}{l}\text { In Percent of } \\
\text { World Exports }\end{array}$ & $\begin{array}{c}\text { In Millions of Barrels } \\
\text { per day } \\
\end{array}$ \\
\hline Angola & 90 & 51 & 1 & 0.7 \\
\hline Equatorial Guinea & 88 & 25 & 0 & 0.1 \\
\hline Oman & 85 & 40 & 2 & 0.9 \\
\hline Nigeria & 82 & 38 & 4 & 1.9 \\
\hline Saudi Arabia & 79 & 29 & 14 & 7.9 \\
\hline Qatar & 78 & 26 & 1 & 0.7 \\
\hline Algeria & 77 & 30 & 2 & 1.2 \\
\hline Congo, Republic of & 77 & 22 & 0 & 0.3 \\
\hline Yemen & 76 & 33 & 1 & 0.3 \\
\hline Kuwait $1 /$ & 68 & 45 & 4 & 2.0 \\
\hline Libya & 67 & 29 & 2 & 1.3 \\
\hline Gabon & 67 & 23 & 1 & 0.3 \\
\hline Iran 2/ & 67 & 22 & 5 & 2.7 \\
\hline Bahrain & 64 & 18 & 0 & 0.2 \\
\hline United Arab Emirates & 60 & 23 & 4 & 2.4 \\
\hline Venezuela & 58 & 17 & 5 & 2.9 \\
\hline Azerbaijan & 37 & 8 & 0 & 0.2 \\
\hline Ecuador & 36 & 11 & 1 & 0.3 \\
\hline Mexico & 31 & 7 & 3 & 1.8 \\
\hline Cameroon & 30 & 6 & 0 & 0.1 \\
\hline Russia 3/ & 30 & 5 & 7 & 3.7 \\
\hline Norway & 29 & 13 & 6 & 3.2 \\
\hline Syria & 28 & 9 & 1 & 0.3 \\
\hline Trinidad and Tobago & 26 & 7 & 0 & 0.2 \\
\hline
\end{tabular}

Sources: IMF staff estimates and US Energy Information Administration.

Note: The definition of oil revenue may well vary across countries, as for the definition of government revenue.

1/ Fiscal year 1999/00.

2/ Fiscal year 2000/01 (estimates).

3 / The estimate of government oil revenue is particularly imprecise due to classification issues.

\section{Why Oil Price Risk Markets Could be a Solution}

The basic problem for oil dependent governments is that they are exposed to large oil price risk which they are ill suited to bear. The answer could be to transfer this risk outside the country to those better able to bear it. This can be done, in theory at least, via oil price risk markets. There are two main ways to do this (for an oil producer), selling oil forward or buying insurance against large price falls. Such hedging could make the government's revenue stream both more stable and predictable. In other words, not only would the government's oil revenue vary less, the government would have time to forsee any change and thus to adjust smoothly.

A futures strategy would lock-in now the oil price the government will receive in the future. For example, assume in drawing up a budget for next year (2002) a government knows for certain that it will receive oil revenue equivalent to 100 million barrels of crude oil multiplied 
by the price it receives per barrel. Without hedging, the government may project an oil price, say $\$ 25$ a barrel, but it would actually receive whatever the spot price turns out to be in 2002 (i.e., the thick 45 degree line in Figure 1). This future spot price cannot be predicted with significant certainty and may well be very different from the current spot price. Under a futures hedging strategy, the government would sell crude futures for 100 million barrels of crude at the 2002 futures price, say $\$ 25$, which would then be the effective ${ }^{4}$ price the government will receive in 2003 (resulting in the horizontal line in Figure 1).

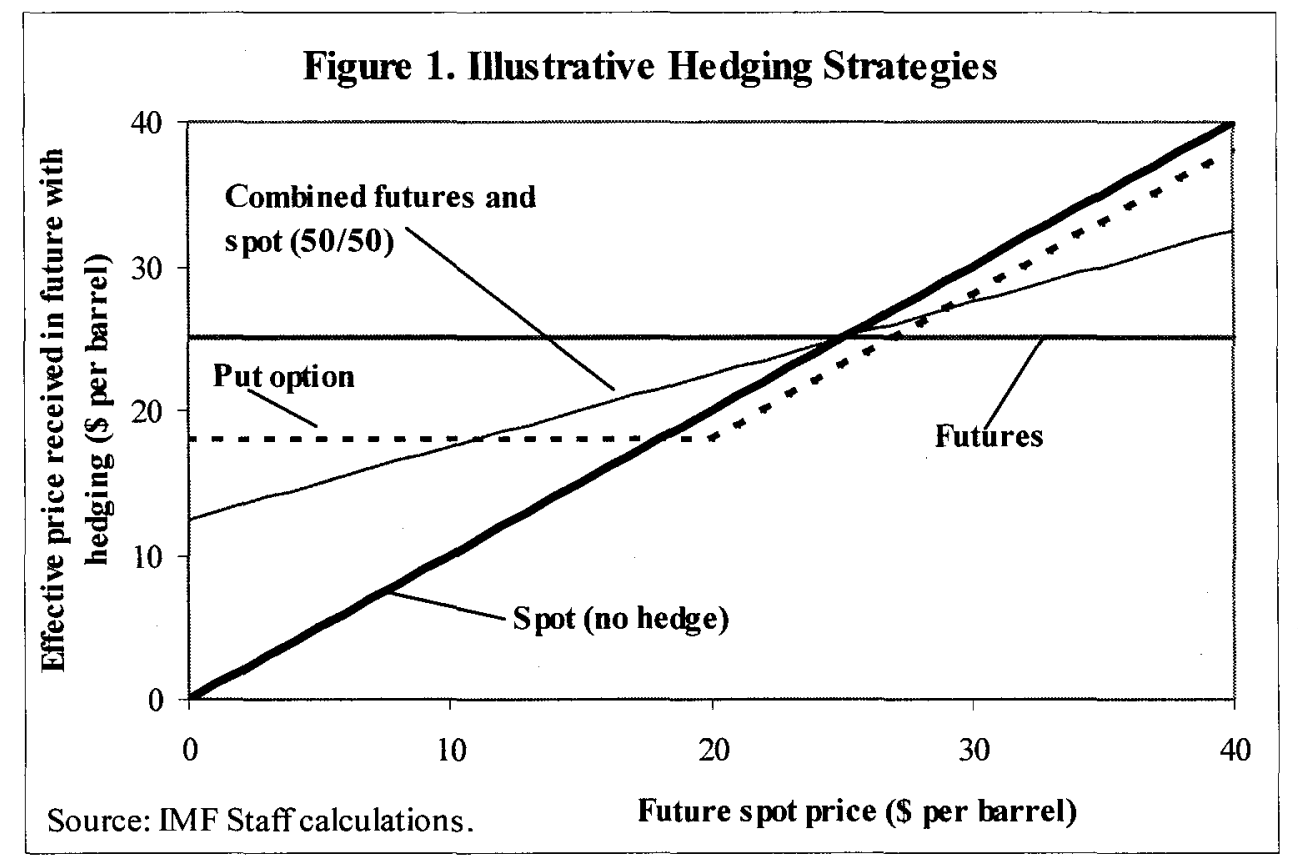

An options strategy would set a minimum price that the government could be sure of receiving in the future. In the example above, the government may decide that it could cope with a 2002 oil price of down to $\$ 20$ but any price below this would cause major difficulties. The government could then buy options to sell ("put" options) crude in 2002 at $\$ 20$ a barrel. If the spot price in 2002 were then to fall below $\$ 20$, the financial gains on the options would bring the effective price up to $\$ 20$ minus the premium (resulting in the dotted kinked line in Figure 1). In contrast to the futures strategy, the options strategy involves a clear up-front cost of the option premium. In effect, the government is buying insurance against a sharp fall in the oil price.

\footnotetext{
${ }^{4}$ It is the "effective" price in that the price received is actually a combination of two operations: the sale of oil on the spot market and the gain/loss on the futures contract. These two operations net out to give a price equal to the futures price.
} 
Hedging strategies can be made very complex to suit the needs of the particular hedger. A simple example illustrated in Figure 1 is the combined futures and spot strategy where half of the output is sold on the futures market and the other half on the spot market. Compared to the option strategy, this combined strategy would still provide some protection against spot price falls but would not involve paying a premium. Compared to the pure futures strategy, the combined strategy would allow the government to benefit from part of higher spot prices in the future, though at the cost of bearing part of any fall. Another common hedging strategy that may be attractive to oil producers is a no-cost collar whereby the cost of buying a premium to protect against sharply lower spot prices in the future is offset by selling an option whereby the oil producer would give up the benefit of sharply higher spot prices. This would thus limit the range of prices the government would receive in the future to a band between the two strike prices.

\section{Hedging simulations}

How would these theoretical hedging strategies have worked in the real world? The simplest simulation of a hedging strategy is to assume that a government has a fixed amount of crude oil to sell every month and that the type of crude it has to sell is exactly the type which is traded on the world's largest oil risk market (New York Mercantile Exchange (NYMEX)). Using historical data for futures and options from NYMEX for the period 1990-July 2001, simple hedging strategies can be simulated.

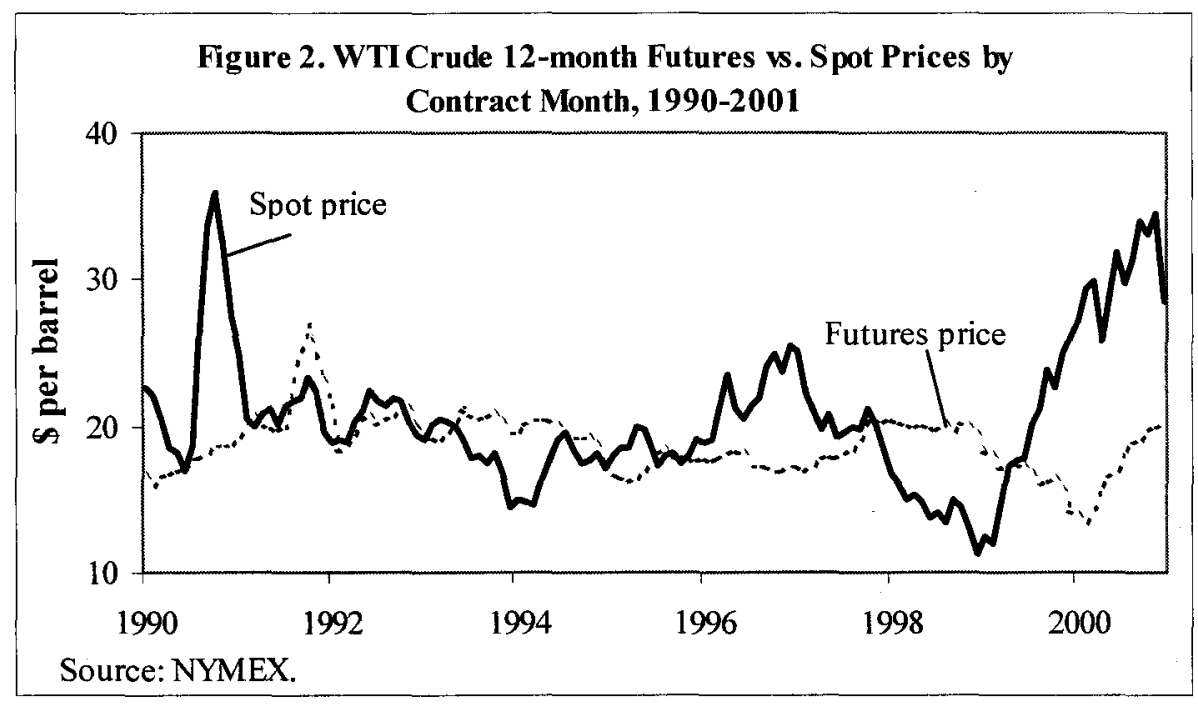

A simple futures strategy would be the government selling its oil via 12-month futures rather than on the spot market. The government would then receive the 12-month futures price

\footnotetext{
${ }^{5}$ Data on futures is available back to 1984 , but continuous data on 12-month futures only goes back to 1990 .
} 
rather than the corresponding ${ }^{6}$ spot price. This would result in a much less volatile revenue stream and a slightly lower average price (see Figure 2) for the sample period. The standard deviation of the average monthly spot price between January 1990 and December 2000 was 4.9 whereas the standard deviation of the corresponding 12 -months futures was only 2.0 . Or in other words, the mean absolute change in the monthly spot price in this period was $\$ 1.33$ compared to $\$ 0.51$ (a reduction of 61 percent) for the 12-months futures contract that expired in the same month. For only one year (1992) out of the ten is this volatility higher for the futures price, and then only by a very small margin and in this year spot prices were comparatively stable.

The reason behind the lower volatility of futures prices can be seen from the shapes of the futures curves for different spot prices (see Figure 3). Figure 3 groups historical oil crude futures curves by their spot price ranges. Thus the bottom line in Figure 3 is the average oil futures curve for all futures curves with a spot price of between $\$ 10$ and $\$ 15$. These curves show that when the spot price is above its historical average, futures prices tend to converge to the historical average, and vice versa. In other words, while the spot price may not be mean-reverting, the futures price tends to be, and the further forward the futures price, the greater the mean reversion. The rationale is probably that market participants believe that there is an equilibrium price to which the spot price will eventually return. Often, market participants see the spot price as influenced by certain clear temporary factors, for example, the weather, an oil accident/pipeline interuption, or the Gulf War.

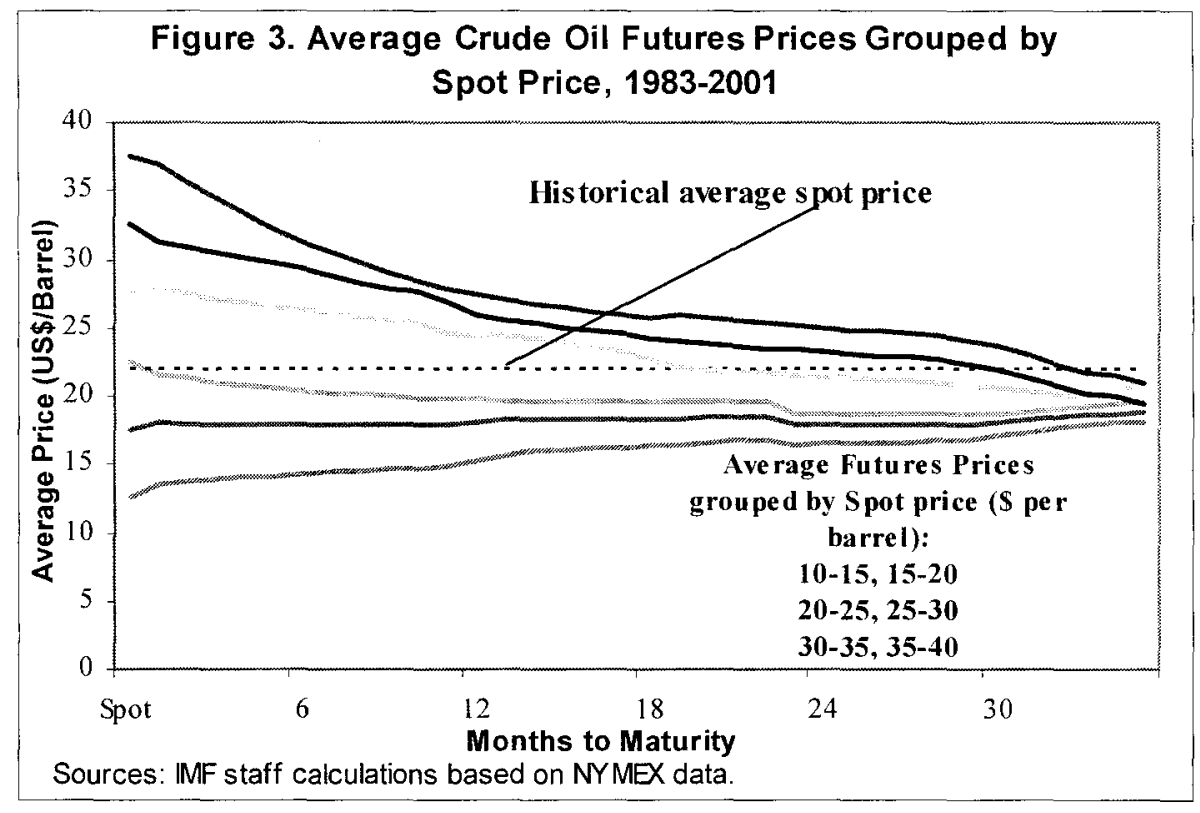

\footnotetext{
${ }^{6}$ Corresponding in the sense that the average spot price for the month of June 2001 is compared to the average price of the 12-month futures contract that has the same delivery month (June 2001).
} 
Over the sample period, the mean average monthly futures price was slightly ( 9 percent) lower than the mean spot price. This would imply that on average an oil producer would have had slightly lower revenue over this period using a futures hedge (and an oil consumer would have had slightly lower cost). However, this result is likely due to the specific sample period. Studies indicate that the futures price is an unbiased estimate of the future spot price (e.g., Kumar, 1993). If this were not the case, there would be scope for arbitrage, which, given the depth and sophistication of the crude futures market, seems unlikely. Indeed, using all 12month futures data from NYMEX over the sample period computed on a daily basis, the difference in the mean prices is trivial (less than 1 percent).

An options strategy also looks able to deliver greater stability at little cost. Simulating an options hedging strategy is more complicated than a futures strategy, reflecting the greater number of choice variables (e.g., strike price) and the frequent lack of observations (e.g., a 12-month put is not always quoted). Figure 4 illustrates a simple strategy: buying 6- to 18month puts at a strike price of $\$ 18$ whenever they are available in the sample period 19902001 (options longer than a few months only became available in the early 1990s).

Compared to the spot price, the options strategy results in a slightly lower effective price than the spot price for most of the period (reflecting the premium), but large gains for a few periods when the spot price fell sharply $(1994,1998) .{ }^{7}$ In fact, the options strategy resulted in a slightly higher effective price than the spot price over the sample period. Because of the missing observations, it is not possible to compare the volatility of the two series, but it seems reasonable to assume that the volatility of the options strategy is lower as it removes two periods of large price movements.

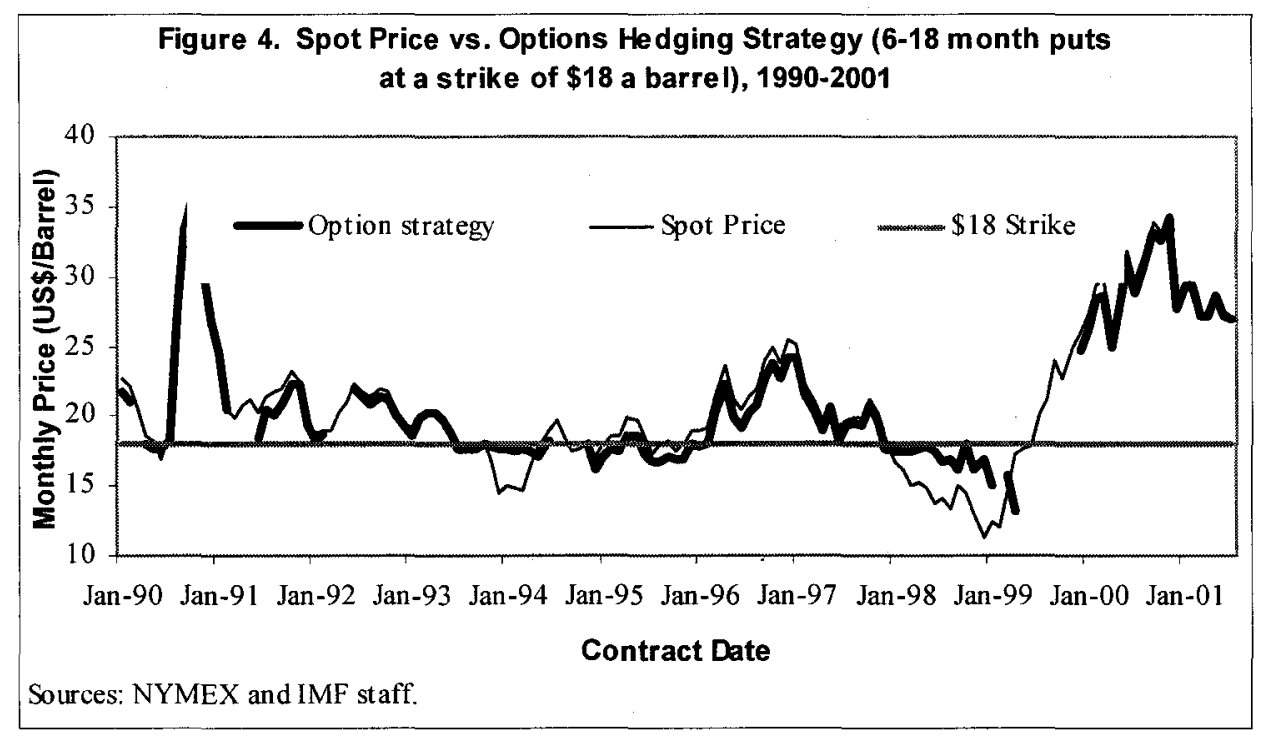

\footnotetext{
${ }^{7}$ The options strategy simulated assumes that the options are European, that is, can only be exercised at maturity. In fact, NYMEX options are American, that is, can be exercised at any time up to maturity, and hence the gains from the options strategy are probably underestimated in this simulation.
} 


\section{Hypothetical hedging simulations for Mexico}

The previous hedging simulation assumed that the type of oil produced by a country is exactly the same as that underlying the type of oil traded on NYMEX. This is not a realistic assumption. Mexico, for example, produces various types of crude that are significantly different from the light, sweet, crudes traded on NYMEX. ${ }^{8}$ Thus to realistically test whether hedging could produce real benefits, hedging strategies should be simulated for countries, such as Mexico, that produce oil types significantly different from those traded on NYMEX.

Simulating some hypothetical basic strategies for Mexico in the period 1990-2000 shows that hedging could have significantly reduced oil price volatility. The simplest strategy is to buy 12-month WTI futures. The return from the hedging strategy is then the Mexican spot price plus the gain/loss from holding the corresponding 12-month WTI futures contract. Figure 5 shows the results from such a hedging strategy and the unhedged strategy (i.e., the Mexican spot price). The standard deviation falls 58 percent, from 4.5 to 1.9. For the sample period, however, the mean price received under the hedging strategy is significantly (12 percent) lower than the spot price. As the difference between the two prices is the gain/loss on the WTI futures contract, and as this gain/loss can be assumed to be unbiased (see above), the lower average price for the hedging strategy presumably reflects the particular sample period.

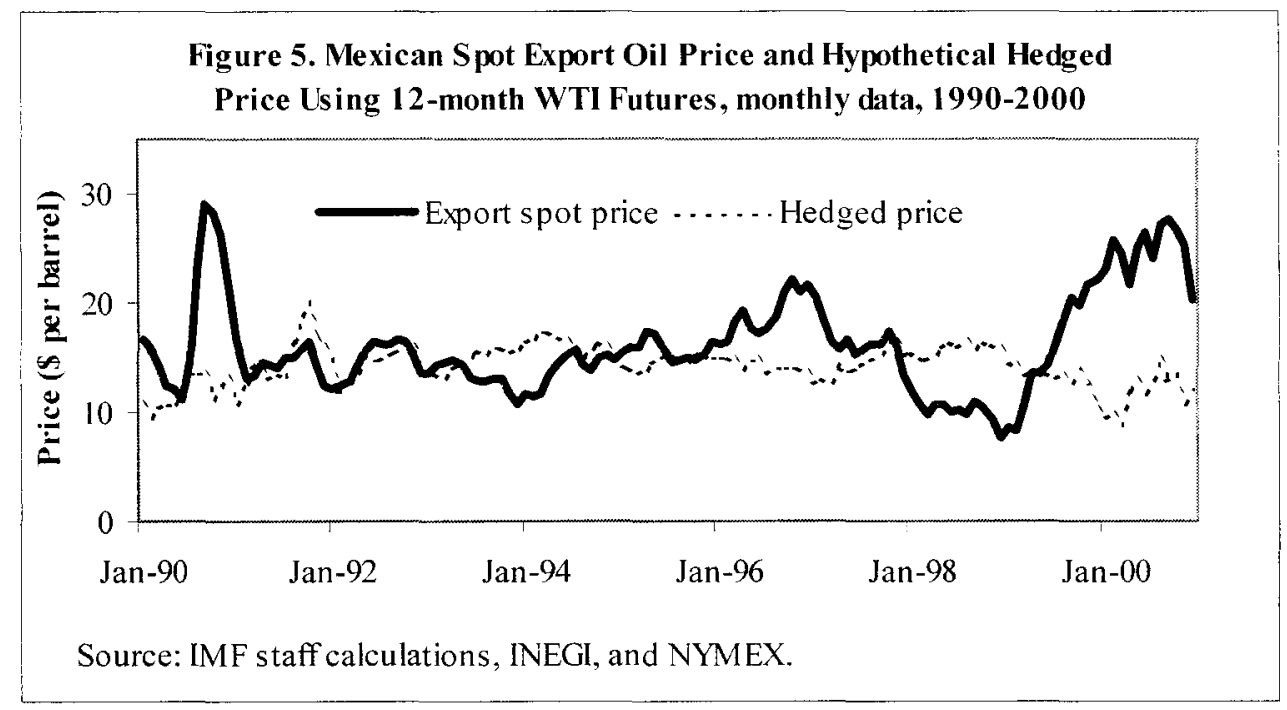

\footnotetext{
${ }^{8}$ Mexico produces three grades of crude oil: heavy Maya-22, which accounts for more than half of total production; light, low-sulfur Isthmus-34, accounting for less than one-third of total production; and extra-light Olmeca-39, which is about one-fifth of total production. Nevertheless, the coefficient of correlation between the Mexican export price and WTI for the period January 1983 and March 2001 is a relatively high 0.95 .
} 


\section{The over-the-counter (OTC) market}

The futures and options traded on an exchange described above will probably not be the most appropriate instrument for hedging government oil price risk, especially for governments (or state-owned oil companies) with less-developed institutional capacity for executing hedging strategies. For these entities, the most appropriate instrument may well be a tailor-made arrangement made directly with a financial intermediary. For example, a government may agree with a financial intermediary that the intermediary would make up to the government any fall in the country's specific crude price below, say, $\$ 15$ a barrel, and that the government would pay over to the intermediary any increase in the spot price above, say, $\$ 35$ a barrel, for a fixed volume of output for the next five years. Such an arrangement would not be traded on an exchange (though the intermediary might lay-off some of the risk via an exchange) and is thus an OTC instrument.

OTC instruments come in many shapes and forms (see Box 1). Their benefits are largely that they remove basis risk, ${ }^{9}$ can be available in very large volumes for singe transactions, are often for longer periods of coverage, and do not usually involve initial deposit or margin calls. However, OTC instruments are usually less transparent and less liquid (and are thus not easily reversed) than exchange-traded instruments. Because OTC transactions are not guaranteed by an exchange, both parties also take greater credit risk. OTC instruments also involve lower overheads (one OTC instrument can cover hedging needs for years), exchange instruments require setting up trading operations such as establishing broker accounts, managing and paying margins, analyzing and monitoring the market in question, ensuring compliance with the exchange's regulations, and, crucially, hiring and supervising traders. Thus, for a country looking to hedge its oil price risk for a long period of time in a one-off operation that can be tailor made to fit its own risk preferences and without involving establishing a trading operation, an OTC transaction may well be most appropriate.

\footnotetext{
${ }^{9}$ Basis risk refers to the risk that the spot price of the object being hedged may move differently from the price of the instrument used to hedge it.
} 


\section{Box 1. The Main Over-the-counter Commodity Risk Instruments}

Forward contracts are agreements to sell or buy a certain product at a certain future time at a preset price. Forward contracts do generally give rise to physical deliveries. A forward contract is like a futures contract, except it is done directly between a buyer and a seller and is usually an OTC instrument. While a commodity forward has certain benefits in common with other OTC instruments (e.g., elimination of basis risk), the much greater liquidity in the futures market makes futures contracts more relevant.

Commodity swaps are basically agreements between two parties to buy or sell a commodity at a fixed price for many periods in the future. Basic ("plain vanilla") commodity swaps involve one party exchanging a fixed price for a floating price. Whereas a futures contract or a forward relates to the price of one transaction in the future, a swap relates to many transactions, often for much longer into the future. For example, a producer could agree the price of its output (e.g., 1 million barrels per quarter) with a financial institution for the next 10 years. If the actual spot price were to fall below the agreed price, the financial institution would make payments to the producer and vice versa. Swaps thus give substantial certainty to future income streams and are often used in the context of project finance, and involve considerable credit exposure for both sides of the transaction.

Commodity bonds and/or loans are bonds or loans with payments (of principal and/or interest) linked to commodity prices. The link can be in two major forms. First, as a loan or bond type whereby a repayment is made with the financial equivalent of a fixed amount of a commodity (e.g., a coupon holder receives the market price of a barrel of oil). Second, as an option type, where the investor can choose whether to receive a fixed financial sum or the financial value of a fixed amount of a commodity. These types of bonds and loans are usually linked to investment projects or to debt rescheduling. Such instruments give investors more confidence about the debtor's ability to pay and allow access to financial markets for firms or countries to which access might otherwise be difficult and on better terms.

Hybrids are combinations of other instruments, for example, a swaption, which is an option to buy or sell a swap.

\section{Why Governments Are Not Using Oll Price Risk Markets}

Information on actual use of commodity risk markets by emerging-market governments (or their state-owned exporting enterprises), with large commodity revenues is patchy and largely anecdotal. This understandably reflects client confidentiality and an unwillingness of producers to reveal market sensitive information. A few cases have been reported however. The most notable was the Mexican use of oil risk markets during the Gulf War (see Box 2). However, market participants generally agree that developing country producer use of risk markets is small in relation to its potential. For example, the World Bank reported in 1999 that "developing countries are estimated to account for only 5 percent of open interest." 10 In contrast, a number of developed country producers (and users) have used commodity risk markets extensively. For example, the state of Texas has hedged its oil revenue with the

\footnotetext{
${ }^{10}$ See World Bank, "Dealing with Commodity Price Volatility in Developing Countries: A Proposal for a Market-Based Approach," September 1999 (page 4).
} 
government executing collar spreads (buying put options and selling call options) to narrow the range in which its revenue stream fluctuates. ${ }^{11}$ What accounts for this lack of use?

\section{Box 2. Mexico's Oil Hedging Strategy}

According to press reports, in late 1990 and during the first half of 1991, Mexico used financial risk management tools to protect its earnings from crude oil exports against a price drop. The strategy reportedly involved selling about 100 million barrels of oil and covered a significant part of its export earnings over this period. Mexico's overall strategy was to ensure that it received at least US\$17 a barrel, the price used as the basis for its 1991 budget. The strategy was quite successful since oil prices fell significantly in early 1991 . Thus, not only did Mexico achieve more certainty ex ante about its oil earnings, it also profited ex post as the gains from having ensured a minimum price exceeded the initial costs of buying the put options.

A senior Mexican official said regarding their hedging program "We said, listen, given the uncertainty and given the volatility, it can go to US\$40 (a barrel) or it can drop to US\$10. We have a budget here, a budget that we have to cover [...] We didn't do it to be ahead. The government does not speculate in that sense. Doing nothing is speculative. It does look good now that we are ahead compared to doing nothing. Some days we do not do as well. But we sleep well."

Source: Washington Post, March 27, 1991.

\section{The politics of hedging}

While it is difficult to be sure, probably the most important constraint on government hedging is political. For an individual Finance Minister (or head of a state oil producer), the political costs of hedging may outweight the benefits, even if the economic case is clear. In the case of a fall in the spot price, any financial gains from a hedging program may be seen as speculative returns. If the Minister had not hedged, it would be easy to blame the international oil markets for any budgetary problems. In the case of the spot price of oil rising, a hedging strategy may well result in the government "missing out" on higher revenue, which would be politically costly. If the government were to use a pure insurance hedging strategy, it may be politically difficult to use scarce resources to pay an option premium rather than, say, build a hospital. Further, the political cost of any operational failure in the hedging program, for example, a rogue trader making massive losses, would be high.

A good illustration of this type of constraint is the political costs suffered by Ecuadoran authorities in early-1993. ${ }^{12}$ The government, through the Central Bank and the Monetary

\footnotetext{
${ }^{11}$ Texas Senator Teel Bivens said on May 1991 about the hedging program that "As long as Texas relies so much on oil revenue, there will always be the chance the state will lose its bet. The state clearly needs a way to hedge its bets."

${ }^{12}$ See Platt's Oilgram News: May 4, 1993. Vol. 71, No. 86, Pg. 6; and May 20, 1993. Vol. 71, No. 98, Pg. 4.
} 
Board, purchased two 3-month and 6-month put options at a strike price of $\$ 14.9$ per barrel. The total premium payments for both options amounted to almost $\$ 12$ million. The government also entered into a six-month swap operation for 5 million barrels under which any excess of the spot price above $\$ 14.9$ per barrel had to be paid by the government. Spot prices turned out to be significantly higher than $\$ 14.9$ per barrel and the government had to let the options expire and pay about $\$ 6$ million on the swap arrangement. Members of the opposition, and even a deputy of the governing party, harshly criticized the operations citing the high losses to the country. Congress also appointed a special committee to investigate "allegations of corruption" against the head of the Central Bank and the president of the Monetary Board.

Overcoming the political constraints to hedging will not be easy, but some steps could be taken. In the international arena, international agencies and research organizations could do more to promote awareness and understanding of hedging opportunities. Individual oildependent countries could explore the scope for hedging their oil price risk with help not only from private-sector companies but also from official and non-profit agencies, like the World Bank or the International Taskforce on Commodity Risk Management. When hedging strategies are adopted, they should be right for the country, operated in a reliable and transparent manner, and presented as insurance against risks rather than as a separate source of revenue. For example, when presenting a budget, the hedging strategy should be presented simultaneously.

\section{Market volume}

Volume limits will constrain large oil producers from hedging, especially beyond six months, but volume does not seem a major constraint for other producers (or consumers).

NYMEX and IPE crude oil open interest ${ }^{13}$ in futures and options beyond six months has recently averaged about 300 million barrels. ${ }^{14}$ OTC crude oil open interest beyond six months is not known, but a rule of thumb suggested by some market participants is that OTC volume is about twice that of exchange-traded instruments. In sum, there may well be open interest of about 1 billion barrels for crude oil price risk beyond six months.

The annual exports of about half of the twenty four heavily oil dependent governments in Table 1 would account for less than a third of the estimated volume currently available. Moreover, the full amount of the exports need not be hedged and once producers start using the market, this may well stimulate greater further increases in volume. Because of the lower

\footnotetext{
${ }^{13}$ Open interest is the number of outstanding contracts, both futures positions which have not been offset and option contracts that have not expired or been exercised.

${ }^{14}$ NYMEX open interest in futures contracts beyond six months is known. Total NYMEX options open interest is known, but is not broken down by maturities. We assume the same maturity profile as for futures. IPE open interest for futures contracts beyond six months is known. However, not even total option open interest is known. We assume the same ratio for the IPE of option open interest to futures open interest as for NYMEX.
} 
exposure to oil price risk for developing consumer governments, volume would be less of a constraint. Indeed, if both consuming and producing governments were to use the market, they would create their own volume.

\section{Creditworthiness and use of reserves}

Governments with a poor credit standing may find their access to certain hedging instruments constrained. For example, a swap transaction would require a financial intermediary to assume the risk that the government would honor its obligations under the swap in the event market prices moves against it for a period of many years. Access to other instruments, such as futures or the purchase of options, would not likely be constrained. Even for the instruments where credit could be a constraint, it need not be binding. Many oil dependent countries already have international credit extended to them in the form of bonds or bank loans and producing countries will bear costs from their hedging operations when they are most likely to be able to afford it (i.e., when the spot price is high). Other forms of credit enhancement could also be available, for example, some part of the oil export earnings could be escrowed or official financing might be available. More generally, however, hedging operations should enhance a country's creditworthiness as the countries would become less vulnerable to oil price movements.

Risk market transactions, especially for less creditworthy countries, often involve significant upfront premia and margin calls. The use of futures requires the deposit of margins ${ }^{15}$ (usually 5-10 percent of the value of the underlying commodity) and the purchase of options requires payment of a premium. Other commodity derivative instruments also require the use of capital for purchasing the instruments or for using collateral to cover performance risk. However, given the leverage derivative transactions can allow, the cost of hedging may well be lower than obtaining similar levels of risk protection though other forms, such as by issuing debt to build up FX reserves. ${ }^{16}$

\section{Fairness of futures prices}

Producers may well consider that market prices for future production are unreasonably low and thus would not be willing to sell their output forward at those prices. These views amount to a belief that commodity-producing governments are better at forecasting the future spot price than the market. For countries with substantial market-moving ability or important

\footnotetext{
${ }^{15}$ These margins do earn interest, however.

${ }^{16}$ For example, if a country wanted to keep a buffer in FX reserves equal to the reduction in one year of oil exports if the oil price fell from $\$ 25$ to $\$ 15$ a barrel and the country exported 40 million barrels a year, this would imply FX reserves of $\$ 400$ million. If, however, the country were to sell the oil forward at $\$ 25$, then it would not lose any revenue if the oil price went to $\$ 15$ and the amount of capital tied up in margin requirements would be about $\$ 100$ million. In other words, futures allow the same amount of protection but at a quarter of the commited FX resources.
} 
inside information, this may be true. But for other governments, it is unlikely to be true, as the historical record of budget forecasting shows. ${ }^{17}$ Also, as discussed previously, past prices are no indication of future prices, and that while the current spot price is an indicator of future spot price, futures market prices are somewhat more accurate and are probably the best estimate available. It is thus difficult, in an ex ante sense, to make the case that futures prices are "unfair."

\section{Institutional capacity and operational risk}

The personnel (and cost) implications of implementing and monitoring hedging operations can be significant. Risk management activities require considerable knowledge of financial instruments and an appropriate institutional framework within which to carry out hedging operations. Expertise is required to understand the risk structure of the company or public sector, identify appropriate risk management instruments and engage in and supervise hedging transactions. The institutional framework should also ensure adequate reporting, recording, monitoring, and evaluation mechanisms, and establish internal control procedures that can protect against speculative transactions and execution errors. Hedging operations are often complex, and without the appropriately developed institutional capacity, can lead to less transparency and foster poor governance.

Not all hedging strategies are equally institutionally demanding. A strategy of continually trading a range of exchange-traded instruments is much more demanding than a single swap transaction. Substantial technical assistance is also available from many sources, for example, from the International Task Force on Commodity Risk Management and the World Bank. ${ }^{18}$ It should also be borne in mind that many countries already undertake complex financial transactions that are little different from oil hedging programs (e.g., central bank hedging of FX or interest rate exposure) and the state-owned oil company may already be involved in short-term oil price risk hedging.

\section{Basis risk}

Exchange-traded instruments may well be only weakly correlated with government revenue. However, this does not necessarily remove the ability to hedge. As the hypothetical example of Mexico described above shows, substantial hedging can still be achieved even if the crude produced differs substantially from the crude traded. Indeed, research suggests that for crude oil exports, about 80 percent of the short-term (less than six months) price risk could be eliminated, and at least 70 percent of the price risk in excess of six months could be

\footnotetext{
${ }^{17}$ See R. Weiner, "Petroleum Fiscal Dependence - Revenue Forecasting and Oil Price Volatility," George Washington University School of Business and Public Management Working Paper No.96-44, December 1996.

${ }^{18}$ The United Nations, under the auspices of the United Nations Conference on Trade and Development (UNCTAD) has developed and implemented an energy price risk management training program for developing countries. Exchanges such as NYMEX and private sector firms can also provide substantial technical assistance.
} 
eliminated, for most crudes. Moreover, OTC instruments can be tailor-made to eliminate, or at least greatly reduce, basis risk.

\section{Market impact}

Forward sales by a large exporter may prompt a disproportionate market reaction, even for a small volume of sales. The possibility of a massive amount of supply and a sea change in the use of risk markets by producers may well push prices down further than justified purely by the size of any one transaction. If the producer is a member of a cartel, for example OPEC, the effect may be even larger. And while confidentiality is possible, it cannot be guaranteed.

Clearly, a large producer cannot try to sell all its output forward well into the future. But that is very different to a modest-sized producer gradually using a wide range of hedging instruments to protect a part of its oil revenue. The experience of Mexico during the Gulf War also indicates that even large producers can successfully execute substantial hedging transactions. Moreover, if futures prices do fall this may bring forward greater demand by consumers to take advantage of low future prices.

\section{ReleVANCE FOR IMF-SUPPORTED ProgramS}

The issue of oil-dependent country use of oil price risk markets is relevant for the IMF. Any actions to reduce oil-dependent country vulnerability to oil price shocks is of general relevance to the IMF, but more specifically, oil price risk hedging could help the success of IMF-supported programs. If the oil price falls without hedging, programs tend to go offtrack: government deficit targets are overshot, growth falls, and external reserve and monetary targets are missed. Programs then either fail or have to be renegotiated from a worse position. Also to help prevent such events, IMF-supported programs require larger net foreign asset targets which are difficult to meet and costly to maintain.

Hedging may help address these problems. If oil revenue (and/or exports) were hedged, the program and the macroeconomy would not be so heavily affected by changes in the oil price, at least not immediately and the government would have time to adjust in an orderly fashion to long-lasting changes in the oil price. Also, lower amounts of foreign exchange reserves need to be kept so that when the oil price falls there will be an immediately offsetting increase in foreign exchange inflows from the hedge. The use of private sector tools and capital to solve macroeconomic problems also helps prevent crises and promotes private sector involvement. This suggests that the IMF should recommend that oil-dependent countries, especially those with an IMF-supported program, should explore the scope for hedging their oil price risk, in conjunction with the World Bank and other official agencies with specialist knowledge in this field. 


\section{Conclusions}

- $\quad$ Many governments are highly exposed to oil price risk which they are ill-suited to bear.

- $\quad$ Traditional methods of dealing with this oil price risk are flawed.

- $\quad$ Oil price risk markets may be a way to deal with this oil price risk. Simulations show that hedging strategies can substantially reduce oil price volatility without significantly reducing return and with the added benefits of greater predictability and certainty.

- Governments so far have not substantially used oil price risk markets. There are probably a number of reasons why, most importantly the political economy of using these markets and a lack of institutional capacity. Large oil producers are also constrained by market size.

- $\quad$ Except for very large oil producers, these constraints seem surmountable. For institutional capacity, there are many sources of technical assistance and much of the operations can be easily outsourced and monitored. For political economy constraints, this requires a greater understanding of the markets by the countries, but it would also benefit from greater attention from major international economic institutions and research groups.

- The IMF should recommend that oil-dependent countries, espeically those with an IMF-supported program, should explore the scope for hedging their oil price risk, in conjunction with the World Bank and other official agencies with specialist knowledge in this field. 


\section{References}

Arrau, Patricio, and Stijn Claessens, 1992, "Commodity Stabilization Funds," World Bank Policy Research Working Paper 835 (Washington: World Bank).

Basch, Miguel, and Eduardo Engel, 1993, "Temporary Shocks and Stabilization Mechanisms: The Chilean Case," in External Shocks and Stabilization Mechanisms, ed. by Eduardo Engel and Patricio Meller (Washington: Inter-American Development Bank).

Cashin, Paul, C. John McDermott, and Alasdair Scott, 1999, "Booms and Slumps in World Commodity Prices," IMF Working Paper 99/155 (Washington: International Monetary Fund).

Cashin, Paul, Hong Liang, and C. John McDermott, 1999, "How Persistent Are Shocks to World Commodity Prices?," IMF Working Paper 99/80 (Washington: International Monetary Fund).

Claessens, Stijn, and Sweder van. Wijnbergen, 1993, “1990 Mexico and Venezuela Recapture Clauses: An Application of Average Price Options," Journal of Banking and Finance, Vol. 17 (June), pp. 733-45.

Claessens, Stijn, and Panos Varangis, 1994, "Oil Price Instability, Hedging, and an Oil Stabilization Fund; The Case of Venezuela," World Bank Policy Research Working Paper 1290 (Washington: World Bank).

Davis, Jeffrey, Rolando Ossowski, James Daniel and Steven Barnett, 2001, "Stabilization and Savings Funds for Nonrenewable Resources: Experience and Fiscal Policy Implications," IMF Occasional Paper 205 (Washington: International Monetary Fund).

Engel, Eduardo, and Patricio Meller, eds., 1993, External Shocks and Stabilization Mechanisms (Washington: Inter-American Development Bank).

Engel, Eduardo, and Rodrigo Valdés, 2000, “Optimal Fiscal Strategy for Oil Exporting Countries,” IMF Working Paper 00/118 (Washington: International Monetary Fund).

Hausmann, Ricardo, 1995, "Dealing with Negative Oil Shocks: The Venezuelan Experience in the Eighties," Working Paper 307 (Washington: Inter-American Development Bank).

Kumar, Manmohan S., 1992, "Forecasting Accuracy of Crude Oil Futures Prices," Staff Papers, International Monetary Fund, Vol. 39 (June), pp. 432-61. 
Spilimbergo, Antonio, 1999, "Copper and the Chilean Economy, 1960-98," IMF Working Paper 99/57 (Washington: International Monetary Fund).

United Nations Conference on Trade and Development, 1996, Price Risk Management in the Fuels Sector: A Manual (New York; Geneva: UNCTAD).

Varangis, Panos, Takamasa Akiyama, and Donald Mitchell, 1995, Managing Commodity Booms - and Busts (Washington: World Bank).

Varangis, Panos, and Don Larson, 1996, "Dealing with Commodity Price Uncertainty," World Bank Policy Research Working Paper 1667 (Washington: World Bank).

Weiner, Robert J., 1996, "Petroleum Fiscal Dependence: Revenue Forecasting and Oil Price Volatility," The George Washington University School of Business and Management Working Paper 96-44 (Washington: George Washington University).

Wickham, Peter, 1996, "Volatility of Oil Prices," IMF Working Paper 96/82 (Washington: International Monetary Fund).

World Bank, 1993, "Venezuela, Oil and Exchange Rates: Historical Experience and Policy Options," World Bank Report No. 10481-VE (Washington).

—_ 1994, "Nigeria-Macroeconomic Risk Management: Issues and Options," World Bank Report No. 11983-UNI (Washington).

— 1999, "Dealing with Commodity Price Volatility in Developing Countries: A Proposal for A Market-Based Approach," Discussion Paper for the Roundtable on Commodity Risk Management in Developing Countries, Washington, September. 